DOI: https://doi.org/10.47405/mjssh.v5i3.414

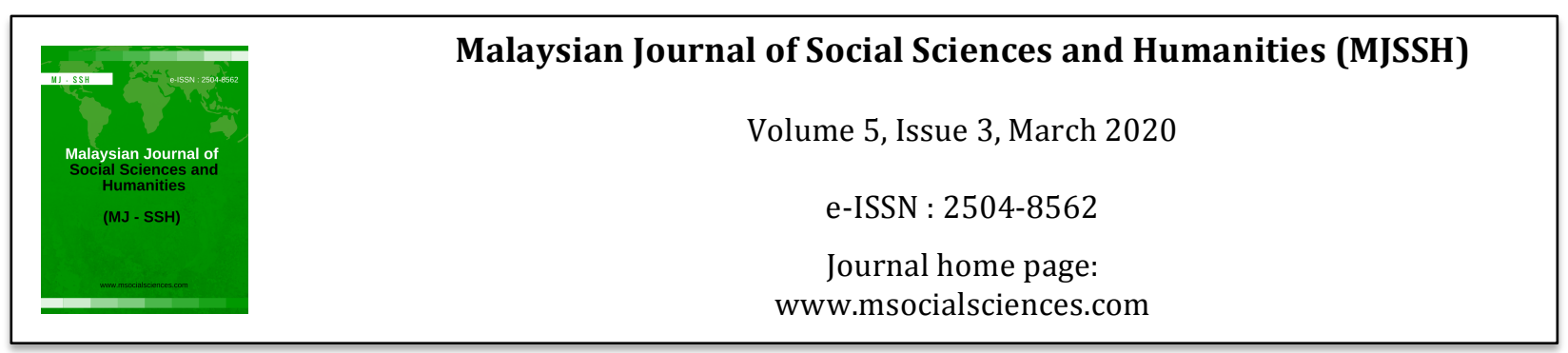

\title{
Penguasaan Konsep Teras Pemikiran Sejarah Melalui Teknik Peer Instruction dan Koleksi Sumber Sejarah
}

\author{
M. Kaviza ${ }^{1}$ \\ 1Pusat Pengajian Pendidikan dan Bahasa Moden, Universiti Utara Malaysia (UUM) \\ Correspondence: M. Kaviza (kavizakaviza@yahoo.com)
}

\begin{abstract}
Abstrak
Kajian secara eksperimen ini bertujuan untuk mengkaji sama ada terdapat peningkatan min penguasaan konsep teras pemikiran sejarah bagi murid yang mengikuti pengajaran dan pembelajaran sejarah melalui teknik Peer Instruction dan koleksi sumber sejarah. Seramai 25 orang murid Tingkatan Empat terlibat dalam kajian ini. Instrumen kajian ini merupakan ujian penguasaan yang telah disahkan oleh panel penilai dan mempunyai nilai kebolehpercayaan, indeks kesukaran dan indeks diskriminasi yang baik. Data kajian ini dianalisis secara deskriptif dan inferensi iaitu ujian-t sampel berpasangan dan ujian-t sampel tak bersandar. Dapatan kajian ini menunjukkan bahawa terdapat peningkatan min penguasaan konsep teras pemikiran sejarah dari segi konsep masa, konsep kepentingan, konsep sebab, konsep perubahan dan konsep perspektif yang signifikan antara ujian pra dan ujian pasca, di samping tidak terdapat perbezaan min penguasaan konsep teras pemikiran sejarah berdasarkan jantina. Implikasi kajian ini mencadangkan kepada pihak guru untuk melaksanakan kaedah pengajaran yang inovatif melalui teknik Peer Instruction dan koleksi sumber sejarah dan bagi membentuk proses pembelajaran yang bermakna.
\end{abstract}

Kata kunci: sumber-sumber sejarah, konsep teras, pemikiran sejarah, teknik peer instruction

\section{Mastering Core Concepts of Historical Thinking Through Peer Instruction Technique and Historical Source Collections}

\begin{abstract}
The experimental study aims to investigate whether there is an increasing of the core concepts of historical thinking through Peer Instruction and historical sources collections. A total of 25 form four students participated in the study. The test which has been validated by panel of expert, has a good reliability, difficulty and discriminant index used as research instruments in this study. The data of this study were analyzed descriptive and inference such as paired sample t-test and independent sample ttest. The findings of this study indicated that there is a significant increasing of the core concepts of historical thinking and also in terms of time concepts, significance concepts, causal concepts, change concepts and perspective concepts between pre and post-test. In addition, the findings also reported that there is no means difference of core concepts of historical thinking based gender. The implications of this study suggested to history teachers to implement the innovative teaching method through Peer Instruction and historical sources collections in line to create a meaningful learning process.
\end{abstract}

Keywords: historical sources, core concepts, historical thinking, peer instruction technique 


\section{Pengenalan}

Oleh kerana penekanan terhadap penerapan kemahiran berfikir menjadi antara aspirasi penting dalam Pelan Pembangunan Pendidikan Malaysia 2013-2025, maka murid-murid perlu diperkukuh dan diperkasakan dengan elemen tersebut secara menyeluruh dalam menghadapi persaingan global yang semakin sengit dalam persekitaran ekonomi yang dipacu oleh inovasi (Kementerian Pendidikan Malaysia [KPM], 2013). Sehubungan dengan itu, kaedah pengajaran yang kurang melibatkan elemen dan tindak balas pemikiran akan menggagalkan matlamat kementerian tersebut dan keadaan ini telah mencadangkan keperluan kepada guru-guru untuk merancang dan melaksanakan kaedah pengajaran yang dapat mengembangkan daya pemikiran murid-murid secara berterusan. Sejajar dengan itu, mata pelajaran sejarah mempunyai teras struktur disiplin yang sistematik bagi mencari kebenaran masa lalu dengan meningkatkan pemikiran yang kritis dan analitis (Pusat Perkembangan Kurikulum [PPK], 2003, 2018). Konsep masa, konsep kepentingan, konsep sebab, konsep perubahan dan konsep perspektif merupakan antara konsep teras pemikiran sejarah yang perlu diterapkan kepada murid-murid (Seixas, 1996; Peck \& Seixas, 2008). Hal ini kerana penguasaan konsep tersebut telah membolehkan murid-murid dapat melihat sesuatu peristiwa sejarah secara empati dan menganalisis bagaimana manusia menggunakan masa, ruang, perubahan dan kesinambungan antara masa silam dengan masa kini. Konsep masa membolehkan murid-murid dapat menyusun rentetan peristiwa secara kronologi dalam memahami proses perkembangan masyarakat dan negara (Fordham, 2014; Turner, Broemmel \& Wooten, 2004), manakala konsep kepentingan memerlukan murid-murid menguasai kemahiran untuk membezakan antara peristiwa yang penting dan yang tidak penting (Conway, 2006). Selain itu, konsep sebab membolehkan murid-murid dapat mengenal pasti punca atau kebenaran sebenar di sebalik suatu peristiwa sejarah yang telah berlaku (Stoel, Van Drie \& Boxtel, 2015), konsep perubahan membolehkan murid dapat memahami secara kritis dan imaginatif tentang segala kehidupan manusia masa sila hingga ke hari ini (Fertig, 2008; Fielding, 2011) dan konsep perspektif pula membolehkan murid-murid memperoleh perspektif yang lebih luas tentang proses perkembangan masyarakat dan negara (Ashby, 2011; Andrew \& Wangdi, 2017). Justeru, kesemua konsep teras pemikiran sejarah tersebut adalah penting kerana murid-murid dapat dibimbing untuk menganalisis dan menilai faktafakta sejarah secara rasional.

Sehubungan dengan itu, teknik Peer Instruction yang diasaskan oleh Eric Mazur merupakan teknik pmbelajaran yang melibatkan konsep penyoalan bagi meningkatkan penglibatan aktif murid di dalam kelas (Mazur, 1997; Budini, Marino, Carreri, Camara \& Giorgi, 2019; Gok, 2014a). Melalui teknik ini, murid-murid boleh berinteraksi antara murid, guru dan bahan untuk memberikan idea mereka atau menyelesaikan permasalahan yang diberikan serta membetulkan kesalahfahaman mereka terhadap sesuatu fakta atau konsep (Rocha \& Souza, 2019; Gok, 2012; Brown \& Demonbrum, 2019). Teknikpembelajaran berpusatkan murid ini telah membolehkana murid-murid dapat mengembangkan kefahaman mereka melalui penerangan dan soal jawab dengan rakan-rakan mereka. Justeru, teknik Peer Instruction ini dapat meningkatkan kefahaman konseptual dengan menyediakan peluang kepada murid-murid mempertimbangkan dan merasionalkan jawapan yang dikemukakan dan pada masa yang sama kemahiran berfikir kritis melalui proses inkuiri dapat dijana dan dipertingkatkan (Safa, 2017; Hestiningtyae, Muhammad \& Matlida \& Nur, 2019; Faikotun \& Ellianawati, 2019). Tambahan pula, sumber sejarah dapat ditakrifkan sebagai bahan bukti sejarah yang menyediakan maklumat tentang sesuatu fakta dan kejadian yang terdiri daripada sumber primer dan sumber sekunder (Hazri Jamil, 2003; Barton, 2018; Moats, 212). Antara contoh sumber-sumber sejarah ialah catatan, laporan, surat, peta, risalah, fotograf, poster dan sebagainya yang diakui dapat menggalakkan proses inkuiri, meningkatkan kemahiran pemikiran, membolehkan melihat sesuatu peristiwa sejarah daripada perspektif yang berbeza, menjana pemahaman sejarah yang mendalam (Diekema, Leary, Haderlie \& walters, 2011; Freidman, 2005; Tally \& Goldenberg, 2005; Coopersmith \& Song, 2017; Waring \& Torrez, 2010). Walaubagaimanapun, pelaksanaan teknik Peer Instruction dengan koleksi sumber sejarah adalah suatu inovasi yang boleh dipratikkan selaras dengan memupuk elemen kemahiran pemikiran dalam kalangan murid yang belum diketahui keberkesanannya yang telah memberikan satu ruang kepada pengkaji kajian ini meneroka pelaksanaan teknik Peer Instruction dengan koleksi sumber sejarah dalam mata pelajaran sejarah dengan memfokuskan kepada peningkatan penguasaan konsep teras pemikiran sejarah. 


\section{Tujuan Kajian}

Kajian ini bertujuan untuk mengenal pasti kesan peningkatan bagi min penguasaan konsep teras pemikiran sejarah dalam kalangan murid yang mengikuti pengajaran dan pembelajaran sejarah melalui teknik Peer Instruction dan koleksi sumber sejarah.

\section{Objektif Kajian}

Objektif kajian ini ialah:

i. Mengenal pasti sama ada terdapat peningkatan yang signifikan bagi min penguasaan konsep teras pemikiran sejarah dari aspek konsep masa, konsep kepentingan, konsep sebab, konsep perubahan dan konsep perspektif antara ujian pra dan ujian pasca.

ii. Mengenal pasti sama ada terdapat perbezaan yang signifikan bagi min penguasaan konsep teras pemikiran sejarah berdasarkan jantina

\section{Soalan Kajian}

Soalan kajian ini ialah:

Adakah terdapat peningkatan yang signifikan bagi min penguasaan konsep teras pemikiran sejarah antara ujian pra dan ujian pasca?

i. Adakah terdapat peningkatan yang signifikan bagi min penguasaan konsep masa antara ujian pra dan ujian pasca?

ii. Adakah terdapat peningkatan yang signifikan bagi min penguasaan konsep kepentingan antara ujian pra dan ujian pasca?

iii. Adakah terdapat peningkatan yang signifikan bagi min penguasaan konsep sebab antara ujian pra dan ujian pasca?

iv. Adakah terdapat peningkatan yang signifikan bagi min penguasaan konsep perubahan antara ujian pra dan ujian pasca?

v. Adakah terdapat peningkatan yang signifikan bagi min penguasaan konsep perspektif antara ujian pra dan ujian pasca?

Adakah terdapat perbezaan yang signifikan bagi min penguasaan konsep teras pemikiran sejarah berdasarkan jantina?

\section{Hipotesis Kajian}

Hipotesis kajian ini ialah:

$\mathrm{H}_{\mathrm{ol}}$ : Tidak terdapat peningkatan yang signifikan bagi min penguasaan konsep teras pemikiran sejarah antara ujian pra dan ujian pasca.

i. $\mathrm{H}_{\mathrm{ola}}$ : Tidak terdapat peningkatan yang signifikan bagi min penguasaan konsep masa antara ujian pra dan ujian pasca.

ii. $\mathrm{H}_{\mathrm{olb}}$ : Tidak terdapat peningkatan yang signifikan bagi min penguasaan konsep kepentingan antara ujian pra dan ujian pasca.

iii. $\mathrm{H}_{\mathrm{olc}}$ : Tidak terdapat peningkatan yang signifikan bagi min penguasaan konsep sebab antara ujian pra dan ujian pasca.

iv. $\mathrm{H}_{\mathrm{old}}$ : Tidak terdapat peningkatan yang signifikan bagi min penguasaan konsep perubahan antara ujian pra dan ujian pasca. 
v. $\mathrm{H}_{\mathrm{ole}}$ : Tidak terdapat peningkatan yang signifikan bagi min penguasaan konsep perspektif antara ujian pra dan ujian pasca.

$\mathrm{H}_{\mathrm{o} 2}$ : Tidak terdapat perbezaan yang signifikan bagi min penguasaan konsep teras pemikiran sejarah berdasarkan jantina.

\section{Metod Kajian}

Kajian berbentuk eksperimen dengan reka bentuk Pre-Experimental: One Group Pretest-Posttest (Cohen, Manion \& Morrison, 2007) ini melibatkan seramai 25 orang murid tingkatan empat. Ujian pencapaian yang telah dibentuk oleh pengkaji dan telah yang disahkan oleh pakar penilai dan mempunyai nilai kebolehpercyaan, indek kesukaran dan diskriminasi yang baik dan diterima merupakan instrumen kajian ini (Nunnally, 1978). Data kajian ini dianalisis secara deskriptif dan inferensi iaitu ujian-t sampel berpasangan dan ujian-t sampel tak bersandar melalui perisian IBM SPSS.

\section{Dapatan Kajian}

\section{Peningkatan min penguasaan konsep teras pemikiran sejarah antara ujian pra dan ujian pasca}

Berdasarkan Jadual 1, min penguasaan konsep teras pemikiran sejarah bagi ujian pasca $(M=34.92$, $S D=0.87)$ adalah lebih tinggi berbanding dengan min ujian pra $(M=50.92, S D=0.50)$. Keputusan ujian-t Sampel Berpasangan pada Jadual 2 telah melaporkan bahawa terdapat peningkatan yang signifikan bagi min penguasaan konsep teras pemikiran sejarah antara ujian pra dan ujian pasca $[t(24)=-12.91$, $p=0.00]$. Justeru, $\mathrm{H}_{\mathrm{o} 1}$ telah berjaya ditolak. Maka, dapat disimpulkan bahawa terdapat peningkatan yang signifikan bagi min penguasaan konsep teras pemikiran sejarah antara ujian pra dan ujian pasca bagi murid-murid yang mengikuti pengajaran dan pembelajaran sejarah melalui teknik Peer Instruction dan koleksi sumber sejarah dalam kajian ini.

Jadual 1: Statistik Deskriptif

\begin{tabular}{ccc}
\hline & Ujian Pra & Ujian Pasca \\
\hline $\mathbf{N}$ & 25 & 25 \\
$\boldsymbol{M}$ & 34.92 & 50.92 \\
$\boldsymbol{S D}$ & 0.87 & 0.50 \\
\hline
\end{tabular}

Jadual 2: Ujian-t Sampel Berpasangan bagi Min Penguasaan Konsep Teras Pemikiran Sejarah

\begin{tabular}{|c|c|c|c|c|c|c|c|c|}
\hline \multirow{3}{*}{$\begin{array}{c}\text { Pasangan pra - } \\
\text { pasca }\end{array}$} & \multicolumn{8}{|c|}{ Perbezaan pasangan } \\
\hline & \multirow[t]{2}{*}{ Min } & \multirow[t]{2}{*}{$\begin{array}{l}\text { Sisihan } \\
\text { piawai }\end{array}$} & \multirow[t]{2}{*}{$\begin{array}{c}\text { Min } \\
\text { ralat } \\
\text { piawai }\end{array}$} & \multicolumn{2}{|c|}{$\begin{array}{c}99 \% \text { selang } \\
\text { keyakinan bagi } \\
\text { perbezaan }\end{array}$} & \multirow[t]{2}{*}{$t$} & \multirow[t]{2}{*}{$d f$} & \multirow[t]{2}{*}{$p$} \\
\hline & & & & Bawah & Atas & & & \\
\hline $\begin{array}{l}\text { Konsep } \\
\text { pemikiran }\end{array}$ & -16.00 & 6.20 & 1.24 & -18.56 & -13.44 & $\begin{array}{c}- \\
12.91\end{array}$ & 24 & 0.00 \\
\hline
\end{tabular}

\section{Perbandingan min penguasaan konsep masa antara ujian pra dan ujian pasca}

Berdasarkan Jadual 3, min penguasaan konsep masa bagi ujian pasca $(M=10.08, S D=0.94)$ adalah lebih tinggi berbanding dengan min ujian pra $(M=7.44, S D=0.98)$. Keputusan ujian-t Sampel Berpasangan pada Jadual 4 telah melaporkan bahawa terdapat peningkatan yang signifikan bagi min penguasaan 
konsep masa antara ujian pra dan ujian pasca $[t(24)=-5.81, p=0.00]$. Justeru, $\mathrm{H}_{\text {ola }}$ telah berjaya ditolak. Maka, dapat disimpulkan bahawa terdapat peningkatan yang signifikan bagi min penguasaan konsep masa antara ujian pra dan ujian pasca bagi murid-murid yang mengikuti pengajaran dan pembelajaran sejarah melalui teknik Peer Instruction dan koleksi sumber sejarah dalam kajian ini.

Jadual 3: Statistik Deskriptif

\begin{tabular}{ccc}
\hline & Ujian Pra & Ujian Pasca \\
\hline $\mathbf{N}$ & 25 & 25 \\
$\boldsymbol{M}$ & 7.44 & 10.08 \\
$\boldsymbol{S D}$ & 0.94 & 0.98 \\
\hline
\end{tabular}

Jadual 4: Ujian-t Sampel Berpasangan bagi Min Penguasaan Konsep Masa

\begin{tabular}{|c|c|c|c|c|c|c|c|c|}
\hline \multirow{3}{*}{$\begin{array}{c}\text { Pasangan pra - } \\
\text { pasca }\end{array}$} & \multicolumn{8}{|c|}{ Perbezaan pasangan } \\
\hline & \multirow[t]{2}{*}{ Min } & \multirow[t]{2}{*}{$\begin{array}{l}\text { Sisihan } \\
\text { piawai }\end{array}$} & \multirow{2}{*}{$\begin{array}{c}\text { Min } \\
\text { ralat } \\
\text { piawai }\end{array}$} & \multicolumn{2}{|c|}{$\begin{array}{c}99 \% \text { selang keyakinan } \\
\text { bagi perbezaan }\end{array}$} & \multirow[t]{2}{*}{$t$} & \multirow[t]{2}{*}{$d f$} & \multirow[t]{2}{*}{$p$} \\
\hline & & & & Bawah & Atas & & & \\
\hline Konsep masa & -2.64 & 2.27 & 0.45 & -3.58 & -1.70 & -5.81 & 24 & 0.00 \\
\hline
\end{tabular}

\section{Perbezaan min penguasaan konsep kepentingan antara ujian pra dan ujian pasca}

Berdasarkan Jadual 5, min penguasaan konsep kepentingan bagi ujian pasca $(M=9.00, S D=0.44)$ adalah lebih tinggi berbanding dengan min ujian pra $(M=5.84, S D=0.48)$. Keputusan ujian-t Sampel Berpasangan pada Jadual 6 telah melaporkan bahawa terdapat peningkatan yang signifikan bagi min penguasaan konsep kepentingan antara ujian pra dan ujian pasca $[t(24)=-6.81, p=0.00]$. Justeru, $\mathrm{H}_{\mathrm{olb}}$ telah berjaya ditolak. Maka, dapat disimpulkan bahawa terdapat peningkatan yang signifikan bagi min penguasaan konsep kepentingan antara ujian pra dan ujian pasca bagi murid-murid yang mengikuti pengajaran dan pembelajaran sejarah melalui teknik Peer Instruction dan koleksi sumber sejarah dalam kajian ini.

Jadual 5: Statistik Deskriptif

\begin{tabular}{ccc} 
& Ujian Pra & Ujian Pasca \\
\hline $\mathbf{N}$ & 25 & 25 \\
$\boldsymbol{M}$ & 5.84 & 9.00 \\
$\boldsymbol{S D}$ & 0.48 & 0.44 \\
\hline
\end{tabular}

Jadual 6: Ujian-t Sampel Berpasangan bagi Min Penguasaan Konsep Kepentingan

\begin{tabular}{|c|c|c|c|c|c|c|c|c|}
\hline \multirow{3}{*}{$\begin{array}{c}\text { Pasangan pra - } \\
\text { pasca }\end{array}$} & \multicolumn{8}{|c|}{ Perbezaan pasangan } \\
\hline & \multirow[t]{2}{*}{ Min } & \multirow[t]{2}{*}{$\begin{array}{c}\text { Sisihan } \\
\text { piawai }\end{array}$} & \multirow{2}{*}{$\begin{array}{c}\text { Min } \\
\text { ralat } \\
\text { piawai }\end{array}$} & \multicolumn{2}{|c|}{$\begin{array}{l}99 \% \text { selang keyakinan } \\
\text { bagi perbezaan }\end{array}$} & \multirow[t]{2}{*}{$t$} & \multirow[t]{2}{*}{$d f$} & \multirow[t]{2}{*}{$p$} \\
\hline & & & & Bawah & Atas & & & \\
\hline $\begin{array}{l}\text { Konsep } \\
\text { kepentingan }\end{array}$ & -3.16 & 2.32 & 0.46 & -4.12 & -2.20 & -6.81 & 24 & 0.00 \\
\hline
\end{tabular}

\section{Perbezaan min penguasaan konsep sebab antara ujian pra dan ujian pasca}

Berdasarkan Jadual 7, min penguasaan konsep sebab bagi ujian pasca $(M=10.64, S D=0.50)$ adalah lebih tinggi berbanding dengan min ujian pra $(M=8.56, S D=0.16)$. Keputusan ujian-t Sampel Berpasangan pada Jadual 8 telah melaporkan bahawa terdapat peningkatan yang signifikan bagi min penguasaan konsep sebab antara ujian pra dan ujian pasca $[t(24)=-4.31, p=0.00]$. Justeru, $\mathrm{H}_{\mathrm{olc}}$ telah 
DOI: https://doi.org/10.47405/mjssh.v5i3.414

berjaya ditolak. Maka, dapat disimpulkan bahawa terdapat peningkatan yang signifikan bagi min penguasaan konsep sebab antara ujian pra dan ujian pasca bagi murid-murid yang mengikuti pengajaran dan pembelajaran sejarah melalui teknik Peer Instruction dan koleksi sumber sejarah dalam kajian ini.

Jadual 7: Statistik Deskriptif

\begin{tabular}{ccc}
\hline & Ujian Pra & Ujian Pasca \\
\hline $\mathbf{N}$ & 25 & 25 \\
$\boldsymbol{M}$ & 8.56 & 10.64 \\
$\boldsymbol{S D}$ & 0.16 & 0.50 \\
\hline
\end{tabular}

Jadual 8: Ujian-t Sampel Berpasangan bagi Min Penguasaan Konsep Sebab

\begin{tabular}{|c|c|c|c|c|c|c|c|c|}
\hline \multirow{3}{*}{$\begin{array}{c}\text { Pasangan pra - } \\
\text { pasca }\end{array}$} & \multicolumn{8}{|c|}{ Perbezaan pasangan } \\
\hline & \multirow[t]{2}{*}{ Min } & \multirow[t]{2}{*}{$\begin{array}{l}\text { Sisihan } \\
\text { piawai }\end{array}$} & \multirow{2}{*}{$\begin{array}{c}\text { Min } \\
\text { ralat } \\
\text { piawai }\end{array}$} & \multicolumn{2}{|c|}{$\begin{array}{c}99 \% \text { selang keyakinan } \\
\text { bagi perbezaan }\end{array}$} & \multirow[t]{2}{*}{$t$} & \multirow[t]{2}{*}{$d f$} & \multirow[t]{2}{*}{$p$} \\
\hline & & & & Bawah & Atas & & & \\
\hline Konsep sebab & -2.08 & 2.41 & 0.48 & -3.08 & -1.08 & -4.31 & 24 & 0.00 \\
\hline
\end{tabular}

\section{Perbezaan min penguasaan konsep perubahan antara ujian pra dan ujian pasca}

Berdasarkan Jadual 9, min penguasaan konsep perubahan bagi ujian pasca $(M=11.00, S D=0.91)$ adalah lebih tinggi berbanding dengan min ujian pra $(M=6.68, S D=0.40)$. Keputusan ujian-t Sampel Berpasangan pada Jadual 10 telah melaporkan bahawa terdapat peningkatan yang signifikan bagi min penguasaan konsep perubahan antara ujian pra dan ujian pasca $[t(24)=-10.40, p=0.00]$. Justeru, $\mathrm{H}_{\mathrm{old}}$ telah berjaya ditolak. Maka, dapat disimpulkan bahawa terdapat peningkatan yang signifikan bagi min penguasaan konsep perubahan antara ujian pra dan ujian pasca bagi murid-murid yang mengikuti pengajaran dan pembelajaran sejarah melalui teknik Peer Instruction dan koleksi sumber sejarah dalam kajian ini.

Jadual 9: Statistik Deskriptif

\begin{tabular}{ccc}
\hline & Ujian Pra & Ujian Pasca \\
\hline $\mathbf{N}$ & 25 & 25 \\
$\boldsymbol{M}$ & 6.68 & 11.00 \\
$\boldsymbol{S D}$ & 0.40 & 0.91 \\
\hline
\end{tabular}

Jadual 10: Ujian-t Sampel Berpasangan bagi Min Penguasaan Konsep Perubahan

\begin{tabular}{|c|c|c|c|c|c|c|c|c|}
\hline \multirow{3}{*}{$\begin{array}{c}\text { Pasangan pra - } \\
\text { pasca }\end{array}$} & \multicolumn{8}{|c|}{ Perbezaan pasangan } \\
\hline & \multirow[t]{2}{*}{ Min } & \multirow[t]{2}{*}{$\begin{array}{l}\text { Sisihan } \\
\text { piawai }\end{array}$} & \multirow{2}{*}{$\begin{array}{l}\text { Min } \\
\text { ralat } \\
\text { piawai }\end{array}$} & $\begin{array}{r}99 \% \text { sel } \\
\text { bagi }\end{array}$ & yakinan & & \multirow[t]{2}{*}{$d f$} & \multirow[t]{2}{*}{$p$} \\
\hline & & & & Bawah & Atas & & & \\
\hline Konsep perubahan & -4.32 & 2.08 & 0.42 & -5.18 & -3.46 & -10.40 & 24 & 0.00 \\
\hline
\end{tabular}

\section{Perbezaan min penguasaan konsep perspektif antara ujian pra dan ujian pasca}

Berdasarkan Jadual 11, min penguasaan konsep perspektif bagi ujian pasca $(M=10.00, S D=0.35)$ adalah lebih tinggi berbanding dengan min ujian pra $(M=6.40, S D=0.50)$. Keputusan ujian-t Sampel Berpasangan pada Jadual 12 telah melaporkan bahawa terdapat perbandingan yang signifikan bagi min penguasaan konsep perspektif antara ujian pra dan ujian pasca $[t(24)=-6.03, p=0.00]$. Justeru, $\mathrm{H}_{\text {ole }}$ telah berjaya ditolak. Maka, dapat disimpulkan bahawa terdapat peningkatan yang signifikan bagi min penguasaan konsep perspektif antara ujian pra dan ujian pasca bagi murid-murid yang mengikuti 
DOI: https://doi.org/10.47405/mjssh.v5i3.414

pengajaran dan pembelajaran sejarah melalui teknik Peer Instruction dan koleksi sumber sejarah dalam kajian ini.

Jadual 11: Statistik Deskriptif

\begin{tabular}{ccc} 
& Ujian Pra & Ujian Pasca \\
\hline $\mathbf{N}$ & 25 & 25 \\
$\boldsymbol{M}$ & 6.40 & 10.00 \\
$\boldsymbol{S D}$ & 0.50 & 0.35 \\
\hline
\end{tabular}

Jadual 12: Ujian-t Sampel Berpasangan bagi Min Penguasaan Konsep Perspektif

\begin{tabular}{|c|c|c|c|c|c|c|c|c|}
\hline \multirow{3}{*}{$\begin{array}{c}\text { Pasangan pra - } \\
\text { pasca }\end{array}$} & \multicolumn{8}{|c|}{ Perbezaan pasangan } \\
\hline & \multirow[t]{2}{*}{ Min } & \multirow[t]{2}{*}{$\begin{array}{c}\text { Sisihan } \\
\text { piawai }\end{array}$} & \multirow{2}{*}{$\begin{array}{l}\text { Min } \\
\text { ralat } \\
\text { piawai }\end{array}$} & \multicolumn{2}{|c|}{$\begin{array}{c}99 \% \text { selang keyakinan } \\
\text { bagi perbezaan }\end{array}$} & \multirow[t]{2}{*}{$t$} & \multirow[t]{2}{*}{$d f$} & \multirow[t]{2}{*}{$p$} \\
\hline & & & & Bawah & Atas & & & \\
\hline Konsep perspektif & -3.60 & 2.99 & 0.60 & -4.83 & -2.37 & -6.03 & 24 & 0.00 \\
\hline
\end{tabular}

\section{Perbezaan min penguasaan konsep teras pemikiran sejarah berdasarkan jantina}

Berdasarkan Jadual 13, min penguasaan konsep teras pemikiran sejarah bagi murid lelaki $(M=51.90$ $S D=0.51)$ adalah lebih tinggi berbanding dengan murid perempuan $(M=50.14, S D=0.50)$. Berdasarkan keputusan ujian Levene's yang tidak signifikan $(F=1.19, p=0.29)$, keputusan ujian-t Sampel Tak Bersandar dalam Jadual 14 telah melaporkan bahawa tidak terdapat perbezaan yang signifikan bagi min penguasaan konsep teras pemikiran sejarah $[t(23)=1.47, p=0.16]$ antara murid lelaki dan murid perempuan. Justeru, $\mathrm{H}_{02}$ telah gagal ditolak. Maka, dapat disimpulkan bahawa min penguasaan konsep teras pemikiran sejarah adalah sama antara murid lelaki dan murid perempuan yang mengikuti pengajaran dan pembelajaran sejarah melalui teknik Peer Instruction dan koleksi sumber sejarah dalam kajian ini.

Jadual 13: Statistik Deskriptif

\begin{tabular}{ccc} 
& Murid Lelaki & Murid Perempuan \\
\hline $\mathbf{N}$ & 11 & 14 \\
$\boldsymbol{M}$ & 51.90 & 50.14 \\
$\boldsymbol{S D}$ & 0.51 & 0.50 \\
\hline
\end{tabular}

Jadual 14: Ujian-t Sampel Tak Bersandar Bagi Min Penguasaan Konsep Pemikiran Sejarah

\begin{tabular}{|c|c|c|c|c|c|c|c|c|c|}
\hline & & & \multicolumn{7}{|c|}{ Ujian-t bagi persamaan min } \\
\hline & \multicolumn{2}{|c|}{$\begin{array}{c}\text { Ujian } \\
\text { Levene's }\end{array}$} & \multirow[t]{2}{*}{$t$} & \multirow[t]{2}{*}{$d f$} & \multirow[t]{2}{*}{$p$} & \multirow[t]{2}{*}{$\begin{array}{l}\text { Perbezaan } \\
\text { min }\end{array}$} & \multirow[t]{2}{*}{$\begin{array}{c}\text { Min } \\
\text { ralat } \\
\text { Piawai }\end{array}$} & \multicolumn{2}{|c|}{$\begin{array}{c}99 \% \text { selang } \\
\text { keyakinan bagi } \\
\text { perbezaan }\end{array}$} \\
\hline & $F$ & $p$ & & & & & & Bawah & Atas \\
\hline Perbezaan Min & 1.19 & 0.29 & 1.47 & 23 & 0.16 & 1.77 & 1.20 & -0.72 & 4.25 \\
\hline
\end{tabular}




\section{Perbincangan Kajian}

Dapatan kajian ini yang menunjukkan bahawa terdapat peningkatan penguasaan konsep teras pemikiran sejarah antara ujian pra dan ujian pasca secara signifikan melalui proses pengajaran dan pembelajaran sejarah melalui teknik Peer Instruction dan koleksi sumber sejarah adalah selaras dengan dapatan kajian Marcus, Levine dan Grenier (2012) dan Young (2012) yang telah melaporkan bahawa penggunaan imej dan muzium dalam pengajaran dan pembelajaran mata pelajaran sejarah berkesan dalam peningkatan pemahaman konsep teras sejarah. Hal ini kerana peluang pembelajaran dengan mengaplikasikan proses pemahaman yang lebih tinggi dapat dijana disebabkan oleh kombinasi teknik Peer Instruction dengan sumber sejarah yang merupakan strategi pembelajaran aktif yang melibatkan aktiviti hands-on dan minds-on. Tambahan pula, peningkatan yang signifikan yang turut dilaporkan dalam konstruk-konstruk konsep teras pemikiran sejarah iaitu konsep masa, konsep kepentingan, konsep sebab-akibat, konsep perubahan dan konsep perspektif dalam kajian ini adalah konsisten dengan dapatan kajian Groot-Reuvekamp, Ros dan Van Boxtel, (2017), kajian Martin (2012), kajian Seixas, (2017), kajian Bickford (2013). Penguasaan konsep teras yang baik dapat memberikan peluang kepada murid-murid untuk membina suatu kefahaman yang mendalam terhadap peristiwa sejarah yang telah berlaku melalui proses pengajaran dan pembelajaran sejarah dengan menggunakan teknik Peer Instruction dengan koleksi sumber sejarah. Pendapat ini adalah bertepatan dengan pendapat Whitehouse (2015), Sandahl (2015), Seixas, (2015) yang telah menjelaskan konsep teras pemikiran sejarah merupakan kerangka yang boleh dipratikkan dalam proses pengajaran sejarah bagi meneroka ilmu sejarah yang dapat membuka ruang pengkajian sejarah yang mendalam. Tambahan pula, dapatan kajian ini yang melaporkan bahawa tidak terdapat perbezaan min penguasaan konsep teras sejarah berdasarkan jantina adalah sealiran dengan dapatan kajian Gok (2014), Miller, kajian Lasry, Lukoff, Schell dan Mazur (2014) dan kajian Gardner, Dutta, Mulcahy, Tabakova, Majewski, Reid \& Jia (2018) yang telah melaporkan bahawa jantina tidak mempengaruhi dalam pelaksanaan teknik Peer Instruction. Hal ini kerana faktor utama yang menentukan penguasaan dan pencapaian seseorang murid ialah pelaksanaan keadah pengajaran dan pembelajaran secara sistematik dan teratur.

\section{Kesimpulan}

Kesimpulannya, teknik Peer Instruction dengan koleksi sumber sejarah dapat meningkatkan penguasaan konsep teras pemikiran sejarah. Implikasi kajian ini telah mencadangkan kepada guru-guru sejarah untuk mempelbagaikan kaedah pengajaran sedia ada dengan teknik Peer Instruction dan koleksi sumber sejarah. Justeru, diharapkan agar pelaksanaan teknik Peer Instruction dengan koleksi sumber sejarah dapat diperluaskan pada semua peringkat persekolahan dalam mencapai matlamat kurikulum sejarah iaitu memberi kefahaman mengenai masyarakat, negara Malaysia dan dunia dengan memupuk identiti diri serta semangat setia negara sebagai warganegara malaysia yang arif dan peka sejarah (PPK, 2018).

\section{Rujukan}

Andrews, G.P., \& Wangdi, Y.P. (2017). The role of agency and memory in historical understanding: Revolution, Reform and Rebellion. Newcastle: Cambridge Scholars Publishing

Ashby, R. (2011). Understanding historical evidence, teaching and learning challenges: Debates in history teaching. New York: Routledge.

Bickford, J.H. (2013). Initiating historical thinking in elementary schools. Faculty Research and Creative Activity, 30.

Barton, K.C. (2018). Historical sources in the classroom: Purpose and use. HSSE Online, 7(2), 1-11.

Brown, M \& Demonbrum, R.M. (2019). Who get helped? The opportunity structure of the college physics classroom, peer instruction and perceptions of help-seeking. Journal of College Science Teaching, 49(2), 36-44.

Budini, N. Marino, Carreri, R, Camero, C \& Giorgi, S. (2019). Perceptions of students after implementing peer instruction in an introductory physics course. Smart Learning Environment, 6(20), 1-8. 
Cohen, L., Manion, L., \& Morrison, K. (2007). Research methods in education (5 ${ }^{\text {th }}$ ed). London: Routledge Falmer.

Conway, R. (2006). What they think they know: The impact of pupil preconceptions on their understanding of historical significance. Teaching History, 125, 10-15.

Coppersmith, S.A \& Song, K.H. (2017). Integrating primary sources, artifacts and museum visit in to the primary years programme inquiry curriculum in an international Baccalaureate elementary setting. Journal of Social Studies education Research, 8(3), 24-49.

Diekema, A.R., Leary, H., Hadelie, S \& Walters, C.D. (2011). Teaching use of digital primary sources for k-12 settings. D-Lib magazine 17(3-4), 1-11.

Faikotun, N \& Ellianawati (2019). Integration of peer instruction in the guided inquiry model: practicing science literacy through scratch. Journal Penelitian \& Pengembangan Pendidikan Fisika, 5(2), 177-182.

Fertig, G. (2008). Using biography to help young learners understand the causes of historical change and continuity. The Social Studies, 99(4), 147-154.

Fielding, A. (2015). Transforming year 11's conceptual understanding of change. Teaching History, $158,28-37$.

Fordham, M. (2014). 'But why then?' Chronological context and historical interpretations. Teaching History, 156, 32- 40.

Freidman, A. (2005). Using digital primary sources to teach world history and world geography: Practice, promise and provisos. Journal of the association for History and Computing, 8(1).

Gardner, G.E., Dutta, S. Mulcahy, K, Tabakova, V, Majewski, D, Reid J.W \& Jia. (2018). A comparative analysis of the use of students response devices (clicker) in university learning environments at a large southeastern university. Journal for STEM Education Research, 1-18.

Gok, T. (2012). The effects of peer instruction on students conceptual learning and motivation. Asia pacific Forum on Science Learning and Teaching, 13(1), 1-17.

Gok, T. (2014a). an investigation of students performances after peer instruction with stepwise problem solving strategies. International Journal of Science and mathematics education, 1-22.

Gok, T. (2014b). Peer instruction in the physics classroom: effects on gender difference performance, conceptual learning and problem solving. Journal of Baltics Science Education, 13(6), 776-788.

Groot-Reuvekamp, M.D., Ros, A \& Van Boxtel, C. (2017). Improving elementary school students understanding of historical time: effects of teaching with "timewise". Theory \& Research in Social Education, 46(1), 35-67.

Hazri Jamil. (2003). Teknik mengajar sejarah. Pahang: PTS Publications \& Distributors.

Harris, F. (2002). There was a Great Collinsion in the stock market: middle school students, online primary sources and historical sense making. School Library Media Research, 5, 422-447.

Hestiningtyae, Y.P, Muhammad, N.H \& Matlida, A \& Nur, J.A. (2019). The impact of guided inquiry model integrated with peer instruction towards science process skills and physics learning achievement. Momentum: Physic Education Journal, 3(2), 78-85.

Kementerian Pendidikan Malaysia. (2013). Pelan Pembangunan Pendidikan Malaysia 2013-2025. Putrajaya: Kementerian Pendidikan Malaysia.

Marcus, A.S., Levine, T.H., \& Grenier, R.S. (2012). How secondary history teacher use and think about museums: current practices and untapped promise for promoting historical understanding. Theory \& Research in Social Education, 40(1), 66-97.

Martin, D. (2012). Using core historical thinking concepts in an elementary history methods course. The History Teacher, 45(4), 581-602.

Mazur, E. (1997). Peer instruction: a user's manual. New Jersey: Prentice Hall

Miller, K., Lasry, N., Lukoff, B., Schell, J \& Mazur, E. (2014). Conceptual question response times in Peer Instruction classroom. Physical Review Special Topic - Physics Education Research, 10, 1 6.

Moats, S. (2012). Teaching with primary sources: A library of congress program. Perspective on history, May, 2012.

Nunnally, J.C. (1978). Psychometrie Theory $\left(2^{\text {nd }}\right.$ Ed). New York: McGraw Hill.

Peck, C., \& Seixas, P. (2008). Benchmarks of historical thinking: First steps. Canadian Journal of Education, 31, 1015-1038.

Pusat Perkembangan Kurikulum. (2003). Huraian sukatan pelajaran tingkatan empat. Kuala Lumpur: Kementerian Pendidikan Malaysia. 
Rocha, M.J.A.D \& Souza, I.C. (2019). Use of clinical cases to teach endocrine physiology by menas of peer instruction and via socrative app. Revista Cubana de investigation Biomedicas, 38(5), 1-2.

Safaa, M.A.H. (2017). The effects of peer instruction method on pre-service teachers' conceptual comprehension of methodology course. Journal of Education and Learning, 6(3), 70-82.

Sandahl, J. (2015). Preparing for citizenship: The value of second order thinking concepts in social science education. Journal of social sciences education, 14(1), 9-30.

Seixas, P. (1996). Conceptualizing the growth of historical understanding. In D. R. Olson \& N. Torrance (Eds.), The handbook of education and human development: New models of learning, teaching and schooling (p. 765-783). Blackwell Publishing.

Seixas, P. (2015). A model of historical thinking. Educational Philosophy and Theory, 49(6), 593-605.

Seixas, P. (2017). Historical consciousness and historical thinking. Palgrave handbook of Research in Historical Culture abd Education, 59-72.

Stoel, G.L., Van Drie, J.P., \& Van Boxtel, C.A.M. (2015). Teaching towards historical expertise: Developing a pedagogy for fostering causal reasoning in history. Journal of Curriculum Studies, 47(1), 49-76.

Tally, B., \& Goldenberg, L.B. (2005). Fostering Historical Thinking with Digitized Primary Resources. Journal of Research on Technology in Education, 38(1), 1-21

Turner, T.N, Broemmel, A.D, \& Wooten, D.A. (2004). History through many eyes: Ten strategies for building understanding of time concepts with historical picture books. Childhood Education, 81(1), 20-24.

Waring, S.M \& Torrez, C. (2012). Using digital primary sources to teach historical perspective to preservice teacher. Contemporary Issues in technology and Teacher Education, 10(3), 294-308.

Whitehouse, J.A. (2018). Historical thinking: A framework for learning and teaching history. Educational Practice and Theory, 37(2), 51-58.

Young, S. (2012). Understanding history through the visual images in historical fiction. Language Art, $89(6), 379-395$. 